Савiна Н. Б. [1; ORCID ID: 0000-0001-8339-1219], д.е.н., професор

${ }^{1}$ Національний університет водного господарства та природокористування, м. Рівне

\title{
ІННОВАЦІЙНА АКТИВНІСТЬ ЯК ОСНОВА ЗАБЕЗПЕЧЕННЯ КОНКУРЕНТОСПРОМОЖНОСТІ ХАРЧОВОЇ ПРОМИСЛОВОСТІ
}

У статті проведено співставне дослідження загальних тенденцій національної економіки та за видом економічних діяльності «виробництво харчових продуктів, напоїв і тютюнових виробів» 3 позиції кількості інноваційно-активних промислових підприємств, витрат на інновації, кількості упровадженої інноваційної продукції, упроваджених у виробництво технологічних процесів, реалізованої інноваційнопромислової продукції. Висвітлено регіональний вимір інноваційної активності на ринку продукції харчової промисловості. Зроблено висновок про співставні тенденції динаміки показників інноваційної діяльності промислових підприємств як усіх промислових підприємств, так промислових підприємств за видом економічної діяльності «виробництво харчових продуктів, напоїв і тютюнових виробів».

Ключові слова: інновації; харчова промисловість; агропродовольчий сектор; виробництво харчових продуктів; інноваційна продукція.

Постановка проблеми. Важливу роль в забезпечені продовольчої безпеки країни відіграє харчова промисловість, що включає більше 40 видів економічної діяльності і статистично зводиться за видом «виробництво харчових продуктів, напоїв i тютюнових виробів». Готова продукція підприємств агропродовольчого сектору національної економіки визнана усьому світі, що підтверджується обсягами експорту. Незважаючи на сталі традиції харчова промисловість України постійно розвивається, підвищуються іï стандарти та запроваджуються інноваційні технології, що передбачають залучення значних інвестицій.

Аналіз останніх досліджень та публікацій. Проблематикою розвитку економіки України в цілому та харчової промисловості зокрема займалися такі вітчизняні науковці Бондаренко С. А., Гринчуцький В.І., Дейнеко Л. В., Коваль В. В., Купінець Л. Є., Пічугіна Т. С., Чорна М.В. та інші. Однак питання інноваційного розвитку потребують подальшого дослідження 3 урахуванням сучасних економічних тенденцій.

Постановка завдання. Метою статті $€$ визначення сучасних тенденцій інноваційної активності окресленої галузі як складової забезпечення конкурентоспроможності підприємств харчової промисловості та її впливу на розвиток агропродовольчого сектору національної економіки.

Виклад основного матеріалу. У 2019 році інноваційною діяльністю в промисловості займалися 782 підприємства, або 15,8\% 
обстежених промислових підприємств. Кількість інноваційноактивних промислових підприємств за 2010-2019 роки зменшилася на 680 , або на $46,5 \%$ в динаміці, при зменшенні загальної кількості промислових підприємств на $53,3 \%$ в динаміці та зростанні частки інноваційно-активних підприємств на 2,0 п.п. за цей же період.

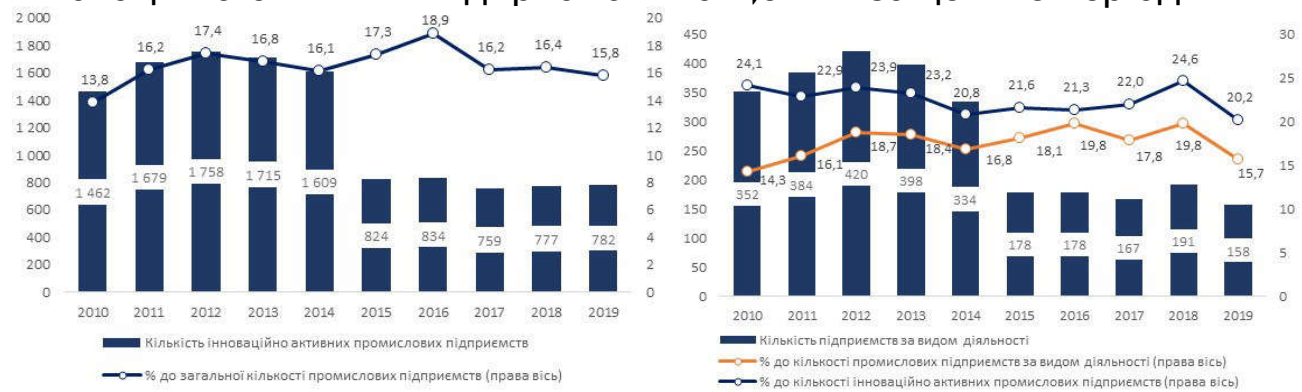

Рис. 1. Кількість інноваційно-активних промислових підприємств всього у

Україні та за видом економічної діяльності «виробництво харчових продуктів, напоїв і тютюнових виробів» у 2010-2019 рр.

Серед регіонів вищою за середню в Україні частка інноваційноактивних підприємств була в Харківській (14\% до загальної кількості інноваційно-активних промислових підприємств), Дніпропетровській $(8,2 \%)$, Запорізькій $(6,0 \%)$, Львівській $(5,6 \%)$, Київській $(5,2 \%)$, Одеській (4,2\%), Полтавській (4,1\%), Черкаській (3,8\%) областях та м. Києві (11,3\%). Найвища частка інноваційно-активних промислових підприємств до загальної кількості промислових підприємств у Тернопільської (29,9\% / 29 підприємств), Харківської (27,1\% / 116) та Миколаївської $(23,2 \%$ / 22) областей.

У розрізі виду економічної діяльності «виробництво харчових продуктів, напоїв і тютюнових виробів» у 2019 році інноваційною діяльністю в займалися 158 підприємств, або 15,7\% обстежених промислових підприємств даного виду економічної діяльності та $20,2 \%$ від загальної кількості інноваційно-активних промислових підприємств. За період 2010-2019 рр. загальна кількість інноваційно-активних підприємств даного виду економічної діяльності зменшилася на 194, або $55,1 \%$ в динаміці. При цьому частка інноваційно-активних промислових підприємств у загальній кількості промислових підприємств частка виду економічної діяльності «виробництво харчових продуктів, напоїв і тютюнових виробів» зросла на 1,4 п.п., з $14,3 \%$ у 2010 році до $15,7 \%$ у 2019 році.

У 2019 році на інновації підприємства витратили 14,2 млрд грн, у тому числі на придбання машин, обладнання та програмного забезпечення - 10,2 млрд грн (71,6\%), на внутрішні та зовнішні науково-дослідні розробки - 2,9 млрд грн (20,5\%), на придбання існуючих знань від інших підприємств або організацій - 0,04 млрд грн $(0,3 \%)$ та на інші роботи, пов'язані зі створенням та впровадженням інновацій (інші витрати), - 1,1 млрд грн (7,6\%). 
Відношення витрат на інновації промислових підприємств до загального обсягу реалізованої промислової продукції (товарів, послуг) у 2019 році становила 0,5\% та зменшилася майже у 2 рази до рівня 2010 року. При цьому, відношення витрат на інновації промислових підприємств до загального обсягу реалізованої інноваційної промислової продукції (товарів, послуг) зросла на 17,6 п.п., зі $23,9 \%$ у 2010 році до $41,5 \%$ у 2019 році (рис. 2 ).
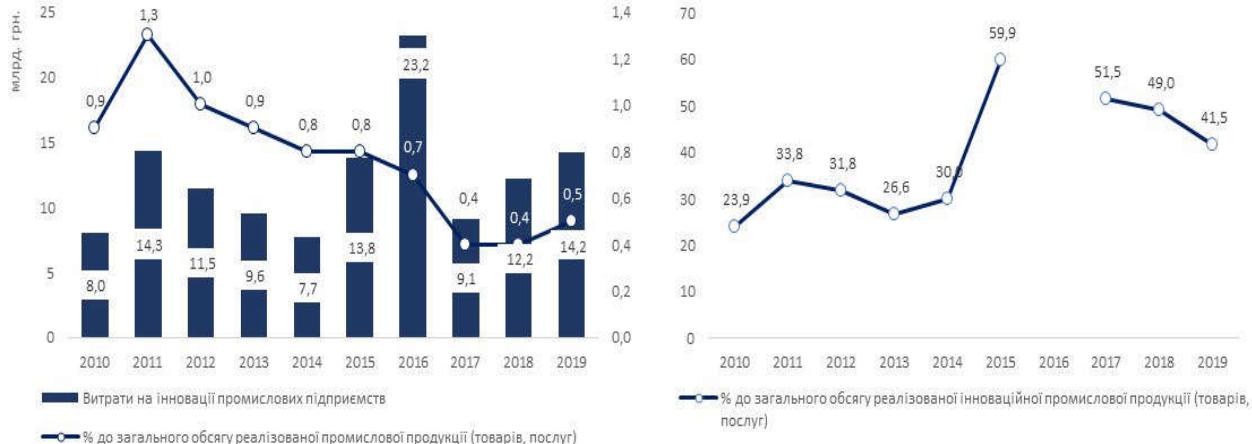

Рис. 2. Витрати на інновації промислових підприємств у 2010-2019 рр.

У 2019 році найбільше коштів витрачено підприємствами м. Києва (3,7 млрд грн, 25,9\%), Дніпропетровської (2,2 млрд грн, 15,6\%), Донецької (1,4 млрд грн, 9,8\%) та Миколаївської (0,9 млрд грн, 6,6\%) областей.

Основним джерелом фінансування інноваційних витрат у 2019 році є власні кошти підприємств - 12,5 млрд грн (або 87,7\% загального обсягу витрат на інновації). Обсяг коштів державного бюджету становив 556,5 млн грн (3,9\%); кошти місцевих бюджетів 109,9 млн грн (0,8\%); кошти вітчизняних інвесторів - 72,3 млн грн $(0,5 \%)$, іноземних $-42,5$ млн грн $(0,3 \%)$, загалом їхній обсяг становив 781,2 млн грн (5,5\%); обсяг кредитів та коштів інших джерел становив 853,2 млн грн (6,0\%) та 111,6 млн грн (0,8 \%) відповідно.

Витрати на інновації промислових підприємств за видом економічної діяльності «виробництво харчових продуктів, напоїв $\mathrm{i}$ тютюнових виробів» у 2019 році становили 3,2 млрд грн, або 22,7\% від загальних витрат на інновації промислових підприємств та зріс на 2,6 млрд грн, або у 4,3 рази до рівня 2010 року, при рості частки у загальних витратах на інновації промислових підприємств на 15,1 п.п., зі 7,6\% у 2010 році до $22,7 \%$ у 2019 році.

У 2019 році відношення витрат на інновації промислових підприємств за видом економічної діяльності «виробництво харчових продуктів, напоїв і тютюнових виробів» до обсягу реалізованої продукції (товарів, послуг) за видом економічної діяльності «виробництво харчових продуктів, напоїв і тютюнових виробів» становило 0,5\%. Дана частка витрат має незначну тенденцію до зростання та зросла на 0,2 п.п., зі 0,3\% у 2010 році до 0,5\% у 2019 р.

Відношення витрат на інновації промислових підприємств за 
видом економічної діяльності «виробництво харчових продуктів, напоїв і тютюнових виробів» до обсягу реалізованої інноваційної продукції (товарів, послуг) за видом економічної діяльності «виробництво харчових продуктів, напоїв і тютюнових виробів» у 2019 році становило 55,8\% та зросла на 42,8 п.п. до рівня 2010 р. (рис. 3).
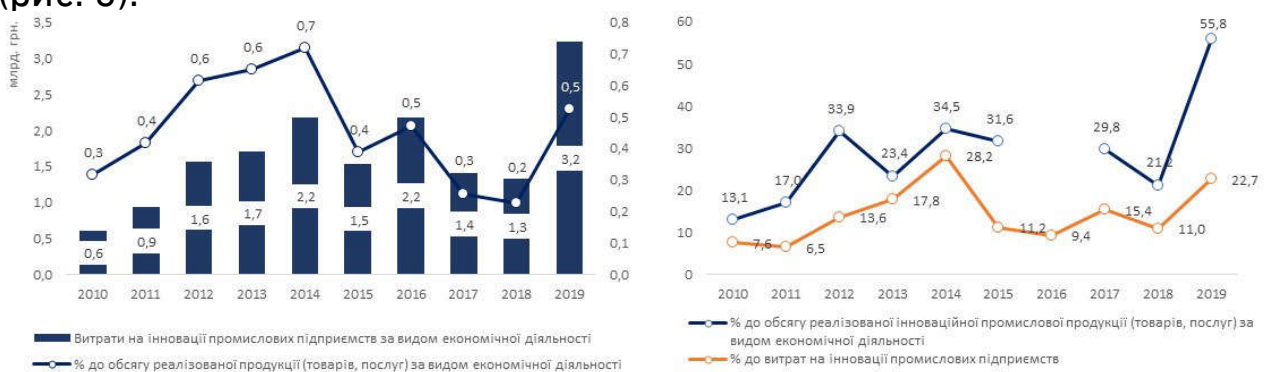

Рис. 3. Витрати на інновації промислових підприємств за видом економічної діяльності «виробництво харчових продуктів, напоїв і тютюнових виробів» у 2010-2019 pp.

У 2019 році $87,9 \%$ інноваційно-активних промислових підприємств упроваджували інновації (або 13,8\% промислових). Ними було впроваджено 2148 інноваційних видів продукції. Із загальної кількості впровадженої продукції 760 (35,4\%) - нові та/або вдосконалені види машин, обладнання, з яких 22,5\% нових для ринку. Найбільшу кількість інноваційних видів продукції впроваджено на підприємствах Харківської (13,0\% загальної кількості упровадженої інноваційної продукції), Запорізької (9,7\%), Сумської (9,4\%), Львівської (9,3\%) областей та м. Києва (8,1\%) (рис. 4).

За видом економічної діяльності «виробництво харчових продуктів, напоїв і тютюнових виробів» у 2019 році 90,5\% інноваційно-активних промислових підприємств упроваджували інновації (або 14,2\% промислових підприємств за даним видом економічної діяльності), якими було впроваджено 591 інноваційних видів продукції (27,5\% загальної кількості упровадженої інноваційної продукції), з яких 73 - нові та/або вдосконалені види машин, обладнання $(12,4 \%)$ (рис. 5$)$.

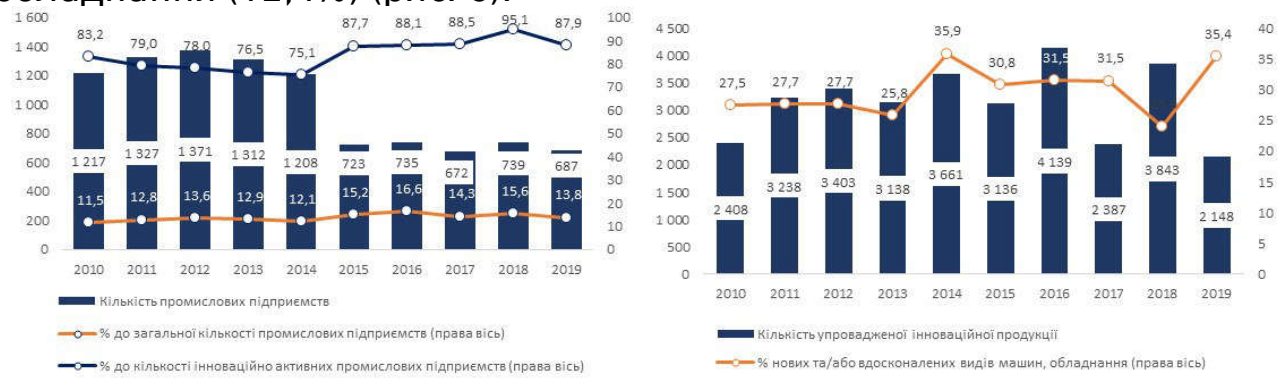

Рис. 4. Кількість промислових підприємств, що впроваджували інновації (продукцію та/або технологічні процеси) та кількість упровадженої інноваційної продукції (товарів, послуг) у 2010-2019 рр. 
Серія «Економічні науки»

Випуск 4(92) 2020 p.

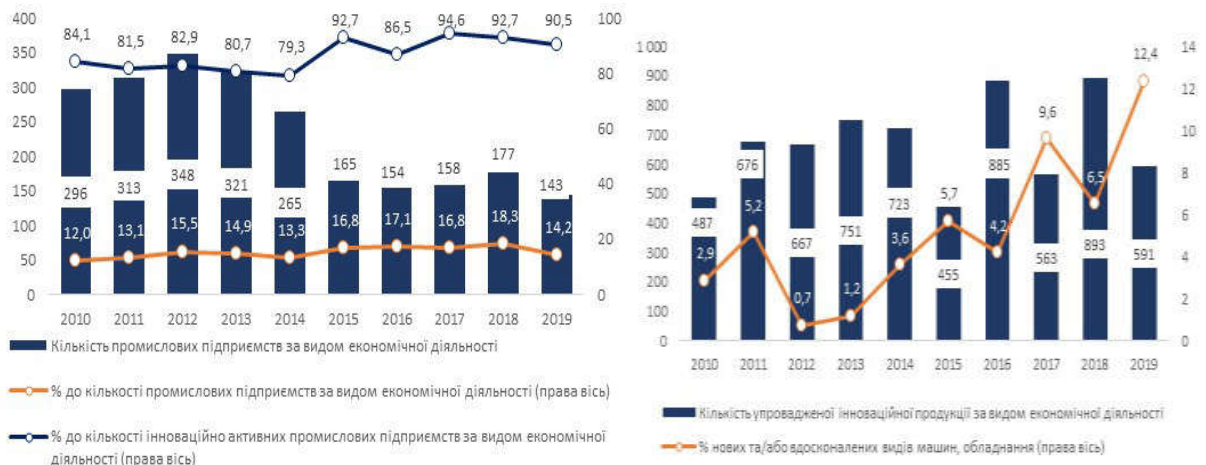

Рис. 5. Кількість промислових підприємств, що впроваджували інновації (продукцію та/або технологічні процеси) та кількість упровадженої інноваційної продукції (товарів, послуг) за видом економічної діяльності «виробництво харчових продуктів, напоїв і тютюнових виробів» у 2010-2019 рр.

У 2019 році кількість упроваджених інноваційних технологічних процесів (нових або вдосконалених методів обробки та виробництва продукції) становила 2318, найбільше 3 яких впровадили підприємства м. Києва (44,0\%), Сумської (12,3\%), Дніпропетровської (7,0\%), Запорізької (6,7\%) областей. Із загальної кількості упроваджених інноваційних технологічних процесів 857 - нові або суттєво поліпшених маловідходних, ресурсозберігаючих технологічних процеси (37,0\%) (рис. 6).
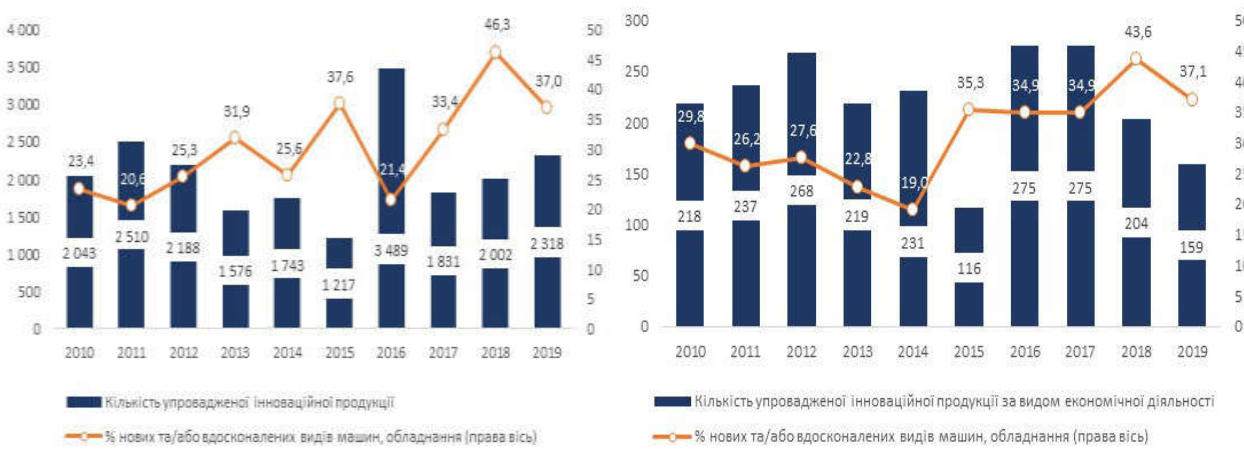

Рис. 6. Кількість упроваджених у виробництво нових технологічних процесів промисловими підприємствами в Україні та за видом економічної діяльності «виробництво харчових продуктів, напоїв і тютюнових виробів» у 2010-2019

pp.

За видом економічної діяльності «виробництво харчових продуктів, напоїв і тютюнових виробів», у 2019 році, кількість упроваджених інноваційних технологічних процесів (нових або вдосконалених методів обробки та виробництва продукції) $159(6,9 \%$ кількості упроваджених інноваційних технологічних процесів), з них нових або суттєво поліпшених маловідходних, ресурсозберігаючих технологічних процесів - 59 (37,1\%). 
У 2019 році підприємства, які здійснювали інноваційну діяльність, реалізували інноваційної продукції на 34,3 млрд грн. Значний обсяг реалізованої інноваційної промислової продукції була новою виключно для підприємства - 80,1\% на 27,4 млрд грн, лише $19,9 \%$ - новою для ринку (6,8 млрд грн). 161 підприємство реалізувало інноваційну продукцію $(20,6 \%$ інноваційно активних промислових підприємств) за межі України на суму 18,6 млрд грн (54,2\% загального обсягу реалізованої інноваційної промислової продукції).

Відношення обсягу реалізованої інноваційної промислової продукції (товарів, послуг) до ВВП України протягом 2010-2019 років знаходиться низькому рівні, в межах 1-3\% та має стійку тенденцію до зниження, зі 3,1\% у 2010 році до $0,9 \%$ у 2019 році. Відношення обсягу реалізованої інноваційної промислової продукції (товарів, послуг) до загального обсягу реалізованої промислової продукції (товарів, послуг) у 2019 році становило 1,3\% та зменшилося на 2,5 п.п. до рівня 2010 р. (рис. 7).

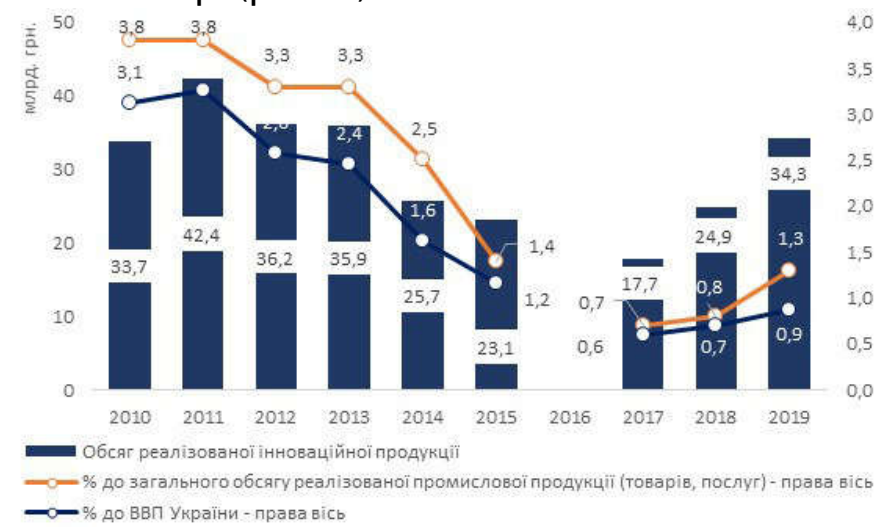

Рис. 7. Обсяг реалізованої інноваційної промислової продукції (товарів, послуг) у 2010-2019 рр.

у 2016 році розрахунок показника не здійснювався

За видом економічної діяльності «виробництво харчових продуктів, напоїв і тютюнових виробів» обсяг реалізованої інноваційної промислової продукції, у 2019 році, становив 5,8 млрд грн (16,9\% загального обсягу реалізованої інноваційної промислової продукції), з яких 85,3\% була новою виключно для підприємства, для ринку - 14,7\%. 37 підприємство реалізувало інноваційну продукцію $(23,4 \%)$ даного виду економічної діяльності за межі України на суму 0,8 млрд грн (13,7\% обсягу реалізованої інноваційної промислової продукції за видом економічної діяльності «виробництво харчових продуктів, напоїв і тютюнових виробів» або 4,3\% загального обсягу реалізованої інноваційної промислової продукції за межі України) (рис. 8). 
Серія «Економічні науки»

Випуск 4(92) 2020 p.

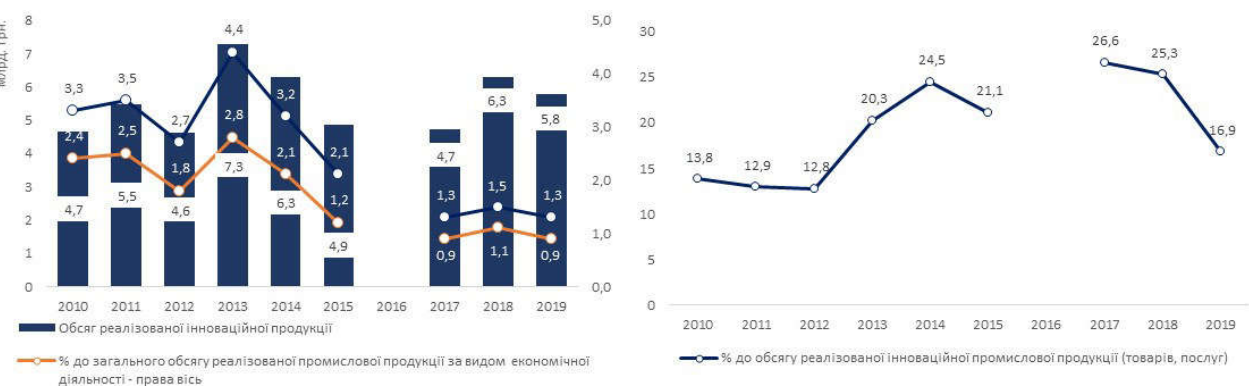

Рис. 8. Обсяг реалізованої інноваційної промислової продукції

(товарів, послуг) за видом економічної діяльності «виробництво харчових

продуктів, напоїв і тютюнових виробів» у 2010-2019 рр.

У 2016 році розрахунок показника не здійснювався

Відношення обсягу реалізованої інноваційної промислової продукції (товарів, послуг) за видом економічної діяльності «виробництво харчових продуктів, напоїв і тютюнових виробів» до ВВП переробної промисловості протягом 2010-2019 років також знаходиться в межах 1-3\% та має стійку тенденцію до зниження, зі $2,4 \%$ у 2010 році до $0,9 \%$ у 2019 році. Відношення обсягу реалізованої інноваційної промислової продукції (товарів, послуг) до обсягу реалізованої продукції (товарів, послуг) за видом економічної діяльності «виробництво харчових продуктів, напоїв і тютюнових виробів» у 2019 році становило 1,3\% та зменшилося на 2,0 п.п. до рівня $2010 \mathrm{p}$.

Висновок. В цілому можна говорити про співставні тенденції динаміки показників інноваційної діяльності промислових підприємств, як усіх промислових підприємств, так промислових підприємств за видом економічної діяльності «виробництво харчових продуктів, напоїв і тютюнових виробів». 3 метою здійснення нововведень підприємства у 2019 році придбали 997 нових технологій, з яких 112 - за межами України, в 2017 році - 961 (129). У 2019 році із загальної кількості технологій 449 придбано 3 устаткуванням, з яких 90 - за межами України; 317 - як результат досліджень і розробок (10); 193 - за договорами на придбання прав на патенти, ліцензії на використання винаходів, промислових зразків, корисних моделей (8); 20 - ноу-хау, угоди на придбання (передачу) технологій (3); 11 - разом з цілеспрямованим прийомом на роботу кваліфікованих фахівців, інші форми придбання - 6 (1). У 2019 році в результаті інноваційної діяльності підприємств створили нові технології, $з$ яких 73 було передано іншим підприємствам, зокрема 4 - за межі України, в 2017 році 61 та 2 відповідно. Це $\epsilon$ свідченням, що інноваційна активність забезпечує конкурентоспроможність харчової промисловості та впливає на розвиток агропродовольчого сектору національної економіки.

1. Держкомстат України. 2. Шеремет А. Д., Сайфулин Р. С., Негашев Е. В. Методика финансового анализа. М.: ИНФРА-М, 1999. 208 с. 3. Бєлов О. В. Кириченко Л. М. 
Методичні підходи до оцінки рівня конкурентоспроможності торгівельного підприємства. Науковий вісник Ужгородського університету. Сер. Економіка. Спецвипуск 33. Ч. 1. С. 18-25. 4. Гернего Ю. О., Підгородецька С. М. Індекси інноваційного розвитку країн світу. Університетські наукові записки. 2014. № 1. C. 339-346. URL: http://nbuv.gov.ua/UJRN/Unzap_2014_1_44 (дата звернення: 20.10.2020). 5. Єріна А. М. Міжнародні рейтинги: статистичні аспекти обчислення та застосування. Індекси інноваційного та людського розвитку. Статистика України. 2016. Ч. II. № 4. С. 66-75. URL: http://nbuv.gov.ua/UJRN/su_2016_4_12 (дата звернення: 20.10.2020). 6. URL: https://www.globalinnovationindex.org/analysisindicator (дата звернення: 20.10.2020). 7. URL: https://lenta.ua/ua/ukrayinapogirshila-pozitsiyi-u-reytingu-innovatsiy-bloomberg-35250/ (дата звернення: 20.10.2020). 8. URL: https://theworldonly.org/rejting-innovatsionnyh-ekonomik-2019/ (дата звернення: 20.10.2020).

\section{REFERENCES:}

1. Derzhkomstat Ukrainy. 2. Sheremet A. D., Sayfulin R. S., Negashev E. V. Metodika finansovogo analiza. M. : INFRA-M, 1999. 208 s. 3. Bielov O. V., Kyrychenko L. M. Metodychni pidkhody do otsinky rivnia konkurentospromozhnosti torhivelnoho pidpryiemstva. Naukovyi visnyk Uzhhorodskoho universytetu. Ser. Ekonomika. Spetsvypusk 33. Ch. 1. S. 18-25. 4. Herneho Yu. O., Pidhorodetska S. M. Indeksy innovatsiinoho rozvytku krain svitu. Universytetski naukovi zapysky. 2014. № 1. S. 339346. URL: http://nbuv.gov.ua/UJRN/Unzap_2014_1_44 (data zvernennia: 20.10.2020). 5. Yerina A. M. Mizhnarodni reitynhy: statystychni aspekty obchyslennia ta zastosuvannia. Indeksy innovatsiinoho ta liudskoho rozvytku. Statystyka Ukrainy. 2016. Ch. II. № 4. S. 66-75. URL: http://nbuv.gov.ua/UJRN/su_2016_4_12 (data zvernennia: 20.10.2020). 6. URL: https://www.globalinnovationindex.org/analysis-indicator (data zvernennia: 20.10.2020). 7. URL: https://lenta.ua/ua/ukrayina-pogirshila-pozitsiyi-ureytingu-innovatsiy-bloomberg-35250/ (data zvernennia: 20.10.2020). 8. URL: https://theworldonly.org/rejting-innovatsionnyh-ekonomik-2019/ (data zvernennia: 20.10.2020).

Savina N. B. [1; ORCID ID: 0000-0001-8339-1219], Doctor of Economics, Professor

${ }^{1}$ National University of Water and Environmental Engineering, Rivne

\section{INNOVATIVE ACTIVITY AS A BASIS FOR ENSURING THE COMPETITIVENESS OF THE FOOD INDUSTRY}

In the article a comparative research of general trends of the national economy and the type of economic activity, e.g. "production of food, beverages and tobacco products" from the standpoint of the number of innovative industrial enterprises, innovation costs, the number of introduced innovative products and technological processes, implemented innovative and industrial products was carried out. The regional dimension of innovation activity in the market of the food industry is highlighted. The conclusion on comparable tendencies of dynamics of industrial enterprises innovative activity indicators was made, including all industrial enterprises 
and the industrial enterprises by type of economic activity «production of food, beverages and tobacco products».

To implement innovations the companies purchased 997 new technologies in 2019, of which 112 are purchased outside Ukraine, 961 new technologies were purchased in 2017, 129 of which from outside Ukraine. In 2019 out of the total number of technologies 449 were purchased with equipment, of which 90 - outside Ukraine; 317 - as a result of research and development (10); 193 - under agreements for the acquisition of rights to patents, licenses for the use of inventions, industrial designs, utility models (8); 20 of them are know-how, namely, agreements on acquisition (transfer) of technologies (3); 11 of which are purposeful recruitment of qualified specialists, and other forms of acquisition are 6 (1). In 2019, as a result of innovative activities of enterprises there were created new technologies, of which 73 were transferred to other enterprises, including 4 - outside Ukraine, and in 2017 there were 61 new technologies created and 2 were transferred to other enterprises. Thus, innovation activity ensures the competitiveness of the food industry and affects the development of the agri-food sector of the national economy.

Keywords: innovations; food industry; agri-food sector; food production; innovative products.

Савина Н. Б. [1; ORCID ID: 0000-0001-8339-1219] д.э.н., профессор

${ }^{1}$ Национальный университет водного хозяйства и природопользования, г. Ровно

\section{ИННОВАЦИОННАЯ АКТИВНОСТЬ КАК ОСНОВА ОБЕСПЕЧЕНИЯ КОНКУРЕНТОСПОСОБНОСТИ ПИЩЕВОЙ ПРОМЫШЛЕННОСТИ}

В статье проведено сопоставимое исследование общих тенденций национальной экономики и по виду экономической деятельности «производство пищевых продуктов, напитков и табачных изделий» с позиции количества инновационно-активных промышленных предприятий, расходов на инновации, количества внедренной инновационной продукции, внедренных в производство технологических процессов, реализованной инновационно-промышленной продукции. Освещено региональное измерение инновационной активности на рынке продукции пищевой промышленности. Сделан вывод о сопоставимых тенденциях динамики показателей инновационной деятельности промышленных предприятий как всех промышленных предприятий, так и промышленных предприятий по виду экономической деятельности «производство пищевых продуктов, напитков и табачных изделий».

Ключевые слова: инновации; пищевая промышленность; агропродовольственный сектор; производство пищевых продуктов; инновационная продукция. 